\title{
COVID-19: ICU delirium management during SARS-CoV-2 pandemic
}

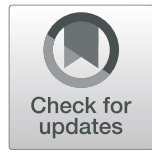

Katarzyna Kotfis ${ }^{1 *}$, Shawniqua Williams Roberson ${ }^{2,3,4}$, Jo Ellen Wilson ${ }^{2,5,6}$, Wojciech Dabrowski, Brenda T. Pun ${ }^{2}$ and E. Wesley Ely $2,6,8$

\begin{abstract}
The novel coronavirus, SARS-CoV-2-causing Coronavirus Disease 19 (COVID-19), emerged as a public health threat in December 2019 and was declared a pandemic by the World Health Organization in March 2020. Delirium, a dangerous untoward prognostic development, serves as a barometer of systemic injury in critical illness. The early reports of $25 \%$ encephalopathy from China are likely a gross underestimation, which we know occurs whenever delirium is not monitored with a valid tool. Indeed, patients with COVID-19 are at accelerated risk for delirium due to at least seven factors including (1) direct central nervous system (CNS) invasion, (2) induction of CNS inflammatory mediators, (3) secondary effect of other organ system failure, (4) effect of sedative strategies, (5) prolonged mechanical ventilation time, (6) immobilization, and (7) other needed but unfortunate environmental factors including social isolation and quarantine without family. Given early insights into the pathobiology of the virus, as well as the emerging interventions utilized to treat the critically ill patients, delirium prevention and management will prove exceedingly challenging, especially in the intensive care unit (ICU). The main focus during the COVID-19 pandemic lies within organizational issues, i.e., lack of ventilators, shortage of personal protection equipment, resource allocation, prioritization of limited mechanical ventilation options, and end-of-life care. However, the standard of care for ICU patients, including delirium management, must remain the highest quality possible with an eye towards long-term survival and minimization of issues related to post-intensive care syndrome (PICS). This article discusses how ICU professionals (e.g., physicians, nurses, physiotherapists, pharmacologists) can use our knowledge and resources to limit the burden of delirium on patients by reducing modifiable risk factors despite the imposed heavy workload and difficult clinical challenges posed by the pandemic.
\end{abstract}

Keywords: COVID-19, Pandemic, SARS-CoV-2, Delirium, Sedation, Pain, PICS, PTSD

\section{Introduction}

The novel coronavirus, SARS-CoV-2-causing Coronavirus Disease 19 (COVID-19), emerged as a public health threat in December 2019 and was declared a pandemic by the World Health Organization in March 2020 [1]. Many hospitalized patients with COVID-19 will develop delirium, and given early insights into the

\footnotetext{
* Correspondence: katarzyna.kotfis@pum.edu.pl

'Department Anaesthesiology, Intensive Therapy and Acute Intoxications, Pomeranian Medical University, Al. Powstańców Wielkopolskich 72, 70-111 Szczecin, Poland

Full list of author information is available at the end of the article
}

pathobiology of this virus indicating invasion into the brain stem, as well as the emerging interventions utilized to treat these critically ill patients, delirium prevention and management may prove exceedingly challenging, especially in the intensive care unit (ICU). In addition to the neurobiology of COVID-19 and typical deliriogenic factors omnipresent in the ICU, this pandemic has created circumstances of extreme isolation and distancing from human contact whenever possible, including loved ones, plus the inability to freely ambulate, which essentially create a "delirium factory" that must be explicitly

(c) The Author(s). 2020 Open Access This article is licensed under a Creative Commons Attribution 4.0 International License, which permits use, sharing, adaptation, distribution and reproduction in any medium or format, as long as you give appropriate credit to the original author(s) and the source, provide a link to the Creative Commons licence, and indicate if changes were made. The images or other third party material in this article are included in the article's Creative Commons licence, unless indicated otherwise in a credit line to the material. If material is not included in the article's Creative Commons licence and your intended use is not permitted by statutory regulation or exceeds the permitted use, you will need to obtain permission directly from the copyright holder. To view a copy of this licence, visit http://creativecommons.org/licenses/by/4.0/ The Creative Commons Public Domain Dedication waiver (http://creativecommons.org/publicdomain/zero/1.0/) applies to the data made available in this article, unless otherwise stated in a credit line to the data. 
addressed to maximize human dignity and respect during care.

In patients with COVID-19, delirium may be a manifestation of direct central nervous system (CNS) invasion, induction of CNS inflammatory mediators, a secondary effect of other organ system failure, an effect of sedative strategies, prolonged mechanical ventilation time, or environmental factors, including social isolation. Drawing from experience with other closely related viruses from the coronaviridae family, direct CNS invasion appears to occur rarely and late in the disease course but may be associated with seizures, impairments in consciousness or signs of increased intracranial pressure $[2,3]$. Such symptoms may require specialized neuro-intensivist management. Immunologic responses to coronaviridae appear to be mediated by acute cytolytic $\mathrm{T}$ cell activation [4]. This response could, if dysregulated, cause an autoimmune encephalopathy [5]. Secondary effects include cerebral hypoxia or metabolic dysregulation in association with failure of pulmonary or other organ systems, such as can be seen in a variety of other types of delirium [6]. Environmental and iatrogenic factors such as prolonged mechanical ventilation, sedatives (especially benzodiazepines), and immobility also contribute heavily to the risk of ICU delirium [7] and can contribute to its development in the context of acute COVID-19 infection.

In an early retrospective report from Wuhan, Mao et al. reported that only $7.5 \%$ had any chart documentation of "impaired consciousness," which was the only term approximating delirium [8]. Underreporting of delirium is extremely common in retrospective chart reviews, and under 1 in 10 with delirium is likely a gross underestimation. The literature is very consistent that $75 \%$ of occurrences of delirium are missed in patients unless objective delirium monitoring is being employed to detect this form of acute brain dysfunction [9-15]. In addition, in COVID-19, the risk of complications such as acquired dementia and ICU-acquired weakness (ICU-AW) as well as depression and PTSD, the defining illnesses of post-intensive care syndrome (PICS), and PICS in family members (PICS-F) [16-18] will be greatly exacerbated if we allow patients to suffer unmitigated delirium.

This article will discuss how ICU professionals (e.g., physicians, nurses, physiotherapists, pharmacologists) can use our knowledge and resources to limit the burden of delirium on patients by reducing modifiable risk factors despite the imposed heavy workload and difficult clinical challenges posed by the pandemic. For example, others have already stressed reasonable analgesia and sedation use with special attention to monitoring and mitigating delirium [19].

\section{COVID-19: Potential factors contributing to ICU delirium}

Delirium, the most frequent clinical expression of acute brain dysfunction [20], is especially important in the context of COVID-19. It may be regarded as an early symptom of infection, as previously described in septic patients [21]. Therefore, delirium should be actively screened for using dedicated psychometric tools, i.e., CAM-ICU [22] or ICDSC [23-26]. It is also plausible that delirium severity, which could be measured with CAM-ICU-7 or DRS-R-98 [27, 28], may be associated with COVID-19 severity [25, 29, 30]. The SARS-CoV-2 virus causes pneumonia, especially in elderly patients $[31,32]$. Since advanced age is a well-described independent risk factor for delirium, it could be postulated that those who are at the greatest risk for severe pulmonary disease related to COVID-19 are likely at the greatest risk for delirium as well. It has been reported that nearly $90 \%$ of COVID-19 patients whose condition required admission to the intensive care unit need mechanical ventilation, either non-invasive (NIV) $(42 \%)$ or invasive requiring intubation (48\%) [33]. Currently, due to the reports of increased aerosolization of the viral load, NIV is not recommended yet still being used when ICU resources become limited [34].

The use of sedating medications in critically ill patients, especially sedative-hypnotics and anticholinergic agents is associated with the development of delirium $[35,36]$. Despite advances in care bundles, such as the ABCDEF bundle [37-39], to reduce the incidence of delirium and improve the care of critically ill patients, recent reports from regions of the world hardest hit by COVID-19 suggest that a flexible approach to management algorithms may be required, due to either a strained workforce or scarcity of resources [40]. Highlighting the importance of COVID-19-related morbidities it must be underlined that agitation associated with hyperactive delirium could theoretically be a source of intra-hospital disease spread in uncooperative patients in over-crowded settings with respiratory distress prior to intubation or awaiting admission to the ICU.

Another potential factor contributing to the occurrence of ICU delirium during the SARS-CoV-2 outbreak is social isolation created by "social distancing" strategies and quarantines, which may prove especially difficult in older adults, who have no or limited support from caregivers. In the age of COVID-19, in an attempt to "flatten the curve" and slow the spread of the virus, many hospitals have instituted no-visitation or very limited visitation policy, which may propagate a sense of isolation, ultimately contributing to disorientation and lack of awareness in the patient. What is needed now, is not only high-quality ICU care, concentrated on providing adequate respiratory support to critically ill patients, but an identification of the source and degree of mental and spiritual suffering of patients as well as their families to provide the most ethical and person-centered care during this humanitarian crisis. Many patients, coming from 
different religious backgrounds, will need the support of religious services that are likely to be unavailable for an extended period of time. Implementation of policies that prevent visitors from coming into the hospital should be followed by additional efforts to support patient-family interaction. This must include dedicated time and effort for phone and video conversations during busy ICU time. Moreover, hospital management should provide all possible novel technological options for communication, including teleconferences or portable speakerphones. All of these concepts are summarized in Fig. 1.

This patient-centered approach is especially important for delirious patients, the majority of whom are elderly, may suffer from an evolving neurocognitive disorder, be hypoactive or aphasic and cannot express their emotional or spiritual needs, and would typically receive comfort from relatives, friends, and caregivers, during a medical crisis. During these strenuous and difficult times, an even deeper sense of humanity is required from healthcare professionals and hospital management to provide quality care to critically ill patients. The workload is already increased with the volume of new and deteriorating patients, but in order to provide maximum humanitarian care and preserve the sense of dignity, we must view the fulfillment of mental and spiritual needs as a medical intervention. Yet it is obvious that during the COVID-19 pandemic, the potential for nonpharmacological interventions encapsulated in the ABCDEF bundle (e.g., mobility outside the ICU room, family engagement) may be extremely limited [26]. All of these issues factor into the type of survivorship that our COVID-19 patients and their families will experience the months and years ahead as they face the burdens of PICS and PICS-F [16-18].

\section{COVID-19: Neuro-invasive potential of SARS- nCoV-2 as cause of delirium}

Acute brain dysfunction, symptomatically presenting as delirium (also called encephalopathy), may be a feature of the neuro-invasive potential of SARS-CoV-2. Neurotropism of coronaviridae has been demonstrated during SARS and MERS epidemics [41-43]. During the 20022003 SARS epidemic older subjects presented not only with respiratory symptoms and typical febrile response, but also with decreased general well-being, poor feeding, and delirium [44]. Given the fact that SARS-CoV and SARS-CoV-2 are similar in terms of pathogenicity, it is quite likely that SARS-CoV-2 has a similar ability to cause delirium [45].

Most CoVs share a common viral structure, infection potential, and neurotropism [46, 47], CoVs are large, enveloped viruses with a large positive-sense, singlestranded RNA genome [48]. Human pathogenic CoVs include those causing recent epidemics, severe acute respiratory syndrome CoV (SARS-CoV and SARS-CoV-2), Middle East respiratory syndrome $\mathrm{CoV}$ (MERS-CoV) HCoV-229E, and other identified coronaviruses, i.e. HCoV-OC43, HCoV-NL63, and HCoV-HKU1 [49-51].

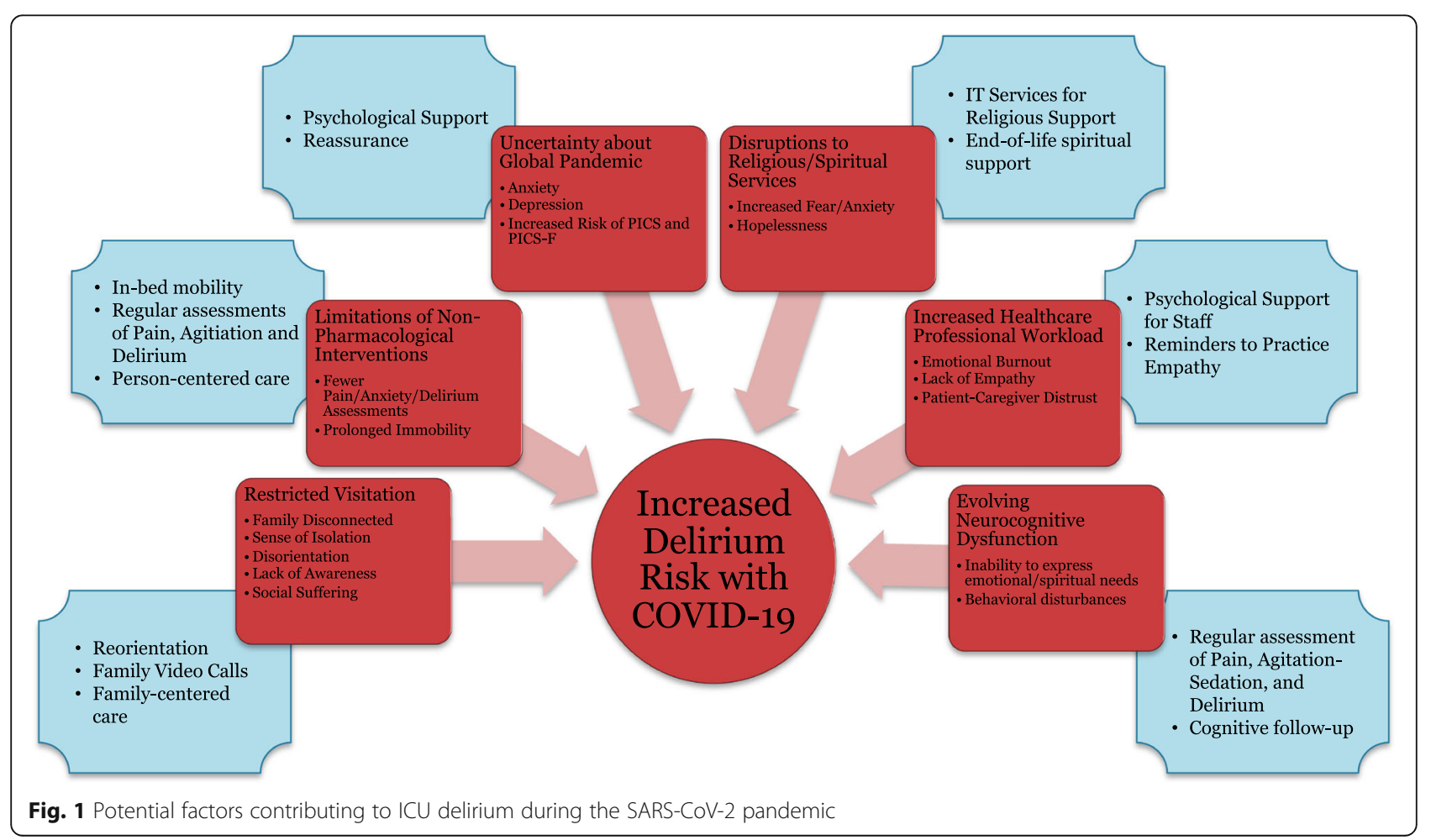


CoVs have been associated with CNS diseases such as acute viral encephalopathy, acute disseminated encephalomyelitis, and multiple sclerosis and are increasingly recognized as presenting a neurologic crisis $[3,52,53]$. In one series of 183 children hospitalized with acute encephalitis, $12 \%$ were associated with coronavirus infection [54]. Such propensity of $\mathrm{CoVs}$ has been documented for several of the beta-CoVs, including SARS-CoV and MERS-CoV [46, 48]. Acute necrotizing encephalitis has also been described in one case of SARS-CoV-2. The patient presented with fever, cough, and altered mental status and was found to have hemorrhagic rim enhancing lesions in the deep gray matter of the cerebral cortex bilaterally [55]. Animal studies suggest coronaviruses are delivered through the peripheral nerves and may access the central nervous system through retrograde synaptic transmission [43, 56, 57]. SARS-CoV spreads in the brains of intranasally inoculated mice primarily via the olfactory bulb with subsequent infection of the hypothalamus and brainstem [57]. Such neuro-invasive potential of SARS-CoV-2 has been postulated to contribute to respiratory failure observed in infected patients [45].

The exact mechanism for neurotoxicity may depend on the brain entry route, which has not been fully elucidated [48]. The SARS-CoVs enter human host cells mainly via a cellular receptor angiotensin-converting enzyme (ACE2), expressed not only in the entire respiratory tract (which it destroys resulting in the leading cause of death), but also in the upper esophagus or enterocytes and showing very low expression level in the brain under normal conditions [45]. The virus entry route may be respiratory, via oro-fecal route, but also directly intranasal $[42,48,58]$. The possible brain entry routes for CoVs, including SARS-CoV-2, include either direct intranasal access to the brain via olfactory nerves (with anosmia as an early symptom) or indirect access to the brain by crossing the blood-brain barrier (BBB) via hematogenous or lymphatic spread $[2,41,59]$.

There are several mechanisms of coronavirus-related brain damage. One of them is connected with the dysfunction of renin-angiotensin system in the brain. ACE is the major component of the cerebral renin-angiotensin system and is localized in the endothelia of cerebral vasculature [60]. The use of ACE inhibitors for treatment of blood hypertension reduces cognitive dysfunction through their anti-inflammatory actions [61]. Circulating reninangiotensin components do not affect the brain with airtight BBB. However, general inflammatory response to virus infection impairs BBB integrity leading to massive infiltration of renin-angiotensin components to the brain [62]. Uncontrolled infiltration of the brain with reninangiotensin components induces neuroinflammatory cascades resulting in extensive neurodegradation followed by cognitive dysfunction [63]. The SARS-CoVs can enter the brain via the $\mathrm{BBB}$ angiotensin-converting enzyme receptors and induce neurodegeneration, astrogliosis, and neuroinflammation. It is noteworthy that SARS-CoV particles have been found in the brain $[41,42]$.

Inflammatory response of the CNS to viral infection seems to be another important reason for poor neurological outcome and occurrence of delirium. A few hours after infection, neutrophils and monocytes infiltrate $\mathrm{CNS}$, and neutrophils seem to be crucial in disruption of BBB permeability [64-66] The postmortem study documented a massive infiltration of the brain by immune cells, which was associated with neuronal edema and the scattered red degeneration [42] Noteworthy, activated macrophages and microglia have been present in areas of demyelination and play a critical role in myelin destruction [66]. The hypomyelinated axons were found in experimental animals with short- and long-term memory deficit, and the degree of myelin disorders was associated with memory dysfunction and short- and long-term cognitive dysfunction $[67,68]$. A large amount of damaged myelin following neuroinflammation is potentially immunogenic and activates macrophages again, which initiate a vicious cycle sustaining further inflammation. This prolonged inflammation may be responsible for the higher incidence of neuropsychological abnormalities in patients with severe infection and sepsis; however, this hypothesis should be confirmed in further studies.

The median time from the onset of first symptoms to the diagnosis of respiratory compromise (dyspnea) is usually 5 days and 8 days from admission to the intensive care unit with severe respiratory failure requiring intubation and mechanical ventilation [45]. The latency period indicates that there might be sufficient time for the coronavirus to enter and destroy CNS neurons.

Previous studies have shown that some patients infected with SARS-CoV-2 present with neurological symptoms such as headache (about $8 \%$ of cases) or centrally mediated nausea and vomiting (about $1 \%$ of cases) [50, 69]. A retrospective study performed by Mao et al., reporting data from 214 COVID-19 patients, showed that neurological symptoms were present in $45 \%$ of severely ill patients, with symptoms including both acute cerebrovascular disease and impaired consciousness [8]. Possibly the neuro-invasive potential of SARS-CoV-2 may be associated with centrally mediated respiratory failure. As a hypothesis, early identification of patients with delirium, being an early symptom of CNS involvement is critical in COVID-19 patients, as it may indicate impending respiratory failure due to the neuro-invasive potential of SARS-CoV-2.

\section{COVID-19: ICU delirium management-potential problems and solutions}

Historically, delirium rates among mechanically ventilated ICU populations were consistently $70-75 \%$, and 
the duration of delirium has consistently proven an independent predictor of longer lengths of stay, higher mortality, greater cost of care, and alarming rates of acquired dementia that lasts years following illness [7073]. Given these facts, it is important to carry into the pandemic the knowledge that delirium in mechanically ventilated patients can be reduced dramatically to $50 \%$ using a culture of lighter sedation and mobilization via the implementation of the safety bundle called the ABCDEFs promoted by the Society of Critical Care Medicine (SCCM) in their ICU Liberation Collaborative [37, 38]. Limitations in the ability to conform to this approach are a major component of the burden of the isolation required to limit the spread of COVID-19, prompting us to discuss specifics related to bedside care that one might keep in mind in organizing busy triage units and routine ICU care during the pandemic.

Delirium screening only takes $30 \mathrm{~s}$. As such, delirium screening and treatment should follow well-established international guidelines, such as the eCASH concept [74] and the SCCM clinical practice guidelines [26]. Although routinely used in clinical practice, some sedation- and delirium-associated issues may be especially important when using limited resources. Standard nonpharmacological measures to treat or prevent delirium may not be possible in isolation environments, and these environments may themselves worsen delirium. Pain management remains a priority for all patients and requires the widespread implementation of behavioral pain scales (CPOT or BPS) for sedated and mechanically ventilated patients. After pain control is adequately assured, we must focus on the intersecting issues that lead a person's brain to fail in critical illness, chief among them including overuse of powerful sedatives and undue immobilization. These and other potential problems regarding ICU delirium management during the SARSCoV-2 pandemic are identified in Table 1.

During such harrowing times at the respiratory failure that is occurring with COVID-19, it would be easy to disregard patients' brains as not being an essential concern. If we follow the critical care literature, this would be a grave error. Evidence indicates that delirium is not only a robust prognostic indicator of worse survival immediately, but also of the cost of care and quality of survival $[71-73,75,76]$. Thus, healthcare professionals should follow local guidelines and policies regarding the monitoring and management of delirium. Implementation of easy screening methods for delirium is necessary especially in light of heavy workload because without validated assessment tools $75 \%$ of delirium will be missed [9-15, 24] during the COVID-19 crisis. It is necessary to reduce the ICU delirium risks using standard management approaches towards adequate pain management, avoiding urinary retention and gastro-intestinal problems (constipation), identification and treatment of nosocomial sepsis, and maintaining adequate oxygenation. Non-pharmacological interventions such as regular orientation despite social separation and lack of contact with family and caregivers are going to prove vitally important.

Regarding pharmacological interventions, no drugs can be recommended for the prevention or treatment of ICU delirium other than avoidance of overuse of potent psychoactive agents like sedatives and neuromuscular blockers (NMB) unless patients absolutely require such management [77-80]. This component of the conversation is especially important given the early anecdotal recommendations to treat patients with COVID-19 in the prone position [81], which will be uncomfortable and thus likely be met with even higher than usual amounts of sedation, which could beget very high rates of delirium down the line in the management of these already high-risk patients. Additionally, it is important to review previous medications to avoid withdrawal symptoms. The ease of COVID-19 transmission and the risk of harm to others (healthcare workers, family, caregivers) may exceed risk of harm to the individual. This is an isolated example warranting earlier use of sedatives for hyperactively delirious patients who are proving harmful to self and others. ICU beds and ventilators are valuable and needed resources so it will be important to consider ways to avoid unnecessary prolongation of ventilation time and ICU length of stay that is associated with deeper sedation. Table 1 provides an overview of ABCDEF bundle adaptations to meet the needs of COVID-19.

\section{Conclusions}

Data regarding delirium in the SARS-CoV-2 pandemic era are thus far too limited. This virus destroys the respiratory tract and invades the CNS, both of which will produce an extremely high-risk circumstance for both acute and long-term brain dysfunction in patients infected with the COVID-19 virus. The further elements of human isolation, extended time away from family and other loved ones, and other elements of care all form what could be construed as a delirium factory that medical teams must address. In the patients with COVID-19, delirium can be a manifestation of direct CNS invasion, induction of CNS inflammatory mediators, secondary effects of other organ system failure, and untoward medical and environmental factors including heavy use of sedatives for prone positioning of the patient and quarantining and social isolation during care. The focus during the COVID-19 pandemic obviously lies within the dire necessity of organizational issues, i.e., lack of ventilators, shortage of personal protection equipment, resource allocation, prioritization of limited mechanical ventilation options, end-of-life care. It is precisely during 
Table 1 COVID-19 delirium management considerations via SCCM's ABCDEF safety bundle framework

\begin{tabular}{|c|c|c|c|}
\hline & Feature & Potential problem during COVID-19 Pandemic & Potential solutions \\
\hline A & $\begin{array}{l}\text { Assessment/ } \\
\text { treatment of } \\
\text { pain }\end{array}$ & $\begin{array}{l}\text { Although regarded as a priority, in intubated, deeply sedated patients, } \\
\text { assessment and management require the use of behavioral pain scales } \\
\text { that may at first glance seem burdensome for strained healthcare } \\
\text { workers but which will ultimately provide the most humane care and } \\
\text { help reduce PTSD. }\end{array}$ & $\begin{array}{l}\text { Regular pain assessment (NRS, CPOT/BPS)_especially } \\
\text { in prone position. } \\
\text { Provide adequate pain management, identify } \\
\text { uncommon sources of pain. } \\
\text { Consider development of peripheral neuropathies } \\
\text { from viral invasion of peripheral nerves and PICS- } \\
\text { related complications. }\end{array}$ \\
\hline B & $\begin{array}{l}\text { Both SAT and } \\
\text { SBT }\end{array}$ & $\begin{array}{l}\text { Stopping both sedation and the ventilator to conduct daily } \\
\text { spontaneous awakening trials and spontaneous breathing trials is } \\
\text { essential. These will not be possible during paralysis in proned patients, } \\
\text { which creates a serious risk-benefit choice of this modality of patient po- } \\
\text { sitioning that argues for the shortest duration possible. Precautions for } \\
\text { early extubation must be used to lower the spread of aerosol }\end{array}$ & $\begin{array}{l}\text { For patients who need NMBD infusion (paralyzed } \\
\text { patients) - monitor NMB depth and shorten duration } \\
\text { whenever possible. } \\
\text { Regularly assess patients with both SBT and SAT daily. }\end{array}$ \\
\hline $\mathrm{C}$ & $\begin{array}{l}\text { Choice of } \\
\text { sedation }\end{array}$ & $\begin{array}{l}\text { Sometimes, deep sedation may be necessary, especially when using } \\
\text { NMBD, when providing high PEEP, and when prone positioning is } \\
\text { implemented. GABA-agonist propofol is likely the best choice during } \\
\text { proning, but this can be shortened via daily questioning of the necessity } \\
\text { of this management approach }\end{array}$ & $\begin{array}{l}\text { Assess with RASS/SAS regularly. } \\
\text { Adjust sedation to ventilation needs-priority lies in } \\
\text { effective ventilation (RASS- } 4 \text { for prone position). } \\
\text { As soon as possible, discontinue potent sedatives or } \\
\text { use those agents that do not suppress the respiratory } \\
\text { drive such as intermittent use of antipsychotics or } \\
\text { alpha-2 agonists. } \\
\text { Remember prolonged ventilation is associated with } \\
\text { poor outcomes. }\end{array}$ \\
\hline D & Delirium & $\begin{array}{l}\text { Hyperactive delirium and agitation can be a source of intra-hospital } \\
\text { cross-infection, especially in agitated patients or during non-invasive } \\
\text { ventilation (if used, not recommended). } \\
\text { Hypoactive delirium is likely to be missed if not monitored for using a } \\
\text { validated instrument routinely. Thus, patients may not receive } \\
\text { appropriate attention to delirium prevention mechanisms. }\end{array}$ & $\begin{array}{l}\text { Provide regular delirium screening (CAM-ICU, ICDSC). } \\
\text { Provide usual non-pharmacological interventions: (1) } \\
\text { orientation is a priority, because patients see health- } \\
\text { care wearing personal protective equipment; (2) sup- } \\
\text { port for senses (hearing aids/glasses); (3) monitor taste/ } \\
\text { smell failure due to CoV predilection to olfactory } \\
\text { nerves (anosmia may be an early sign). } \\
\text { Limit the use of CNS-active medications to agitated } \\
\text { patients. } \\
\text { When CAM-ICU or ICDSC positive, use the Dr. DRE } \\
\text { mnemonic to consider chief delirium risks: Diseases } \\
\text { (new nosocomial infections, acquired heart failure); } \\
\text { Drug Removal, stop all unnecessary psychoactive med- } \\
\text { ications, be on the lookout for withdrawal if the pa- } \\
\text { tient was on a prolonged course of sedatives; } \\
\text { Environment, maximize sleep, orientation to other } \\
\text { humans, minimize sensory deprivation. }\end{array}$ \\
\hline E & Early mobility & $\begin{array}{l}\text { Physiotherapy may be very limited due to heavy workload and } \\
\text { epidemiologic precautions; infusion of NMBD may be necessary. }\end{array}$ & $\begin{array}{l}\text { Physiotherapy must be adjusted to heavy workload } \\
\text { and epidemiologic precautions. } \\
\text { Use passive physiotherapy interventions during the } \\
\text { infusion of NMBD. }\end{array}$ \\
\hline $\mathbf{F}$ & $\begin{array}{l}\text { Family } \\
\text { presence }\end{array}$ & $\begin{array}{l}\text { Limited or no family presence during the pandemic due to quarantine } \\
\text { and social distancing. } \\
\text { A major issue for elderly and as end-of-life problem. }\end{array}$ & $\begin{array}{l}\text { Orientate both patients and family regularly, provide } \\
\text { phone conversations and video conferences, use } \\
\text { technology devices, headphones, and tele-medicine } \\
\text { tools. } \\
\text { Provide visual and vocal contact with the family/ } \\
\text { caregivers/friends, especially for all dying patients } \\
\text { despite isolation, lack of time, and heavy workload. }\end{array}$ \\
\hline
\end{tabular}

BPS behavioral pain scale, CAM-ICU cognitive assessment method for intensive care unit, CNS central nervous system, CoV coronavirus, CPOT critical pain observation tool, ICDSC intensive care delirium screening checklist, NMBD neuromuscular blocking drugs, NRS numeric rating scale, PEEP positive end-expiratory pressure, PICS post-intensive care syndrome, SAT spontaneous awakening trial, SBT spontaneous breathing trial

such times that standardization of safety concerns encapsulated in the ABCDEF bundle can provide a framework to help us accomplish "whole person" care that will help with acute management success as well as improvement of long-term survivorship and reductions of PICS and PICS-F burden on individuals and society as a whole. At the heart of this safety bundle lies the brain, the most vital organ of the human body, and it has been shown now in over 25,000 patients $[37,39,82,83]$ that higher compliance yields better survival, less delirium and coma, shorter lengths of stay, less ICU bounce-back, and lower cost of care. Implementation at the bedside of excellent delirium prevention and management should be a priority during the COVID-19 pandemic [84, 85]. 


\section{Acknowledgements}

We would like to thank Ms. Holly Stevens from the Critical Illness, Brain Dysfunction, and Survivorship (CIBS) Center at Vanderbilt University Medical Center for technical support provided with this manuscript.

\section{Authors' contributions}

Each author has made substantial contribution to this manuscript and has approved the submitted version and agreed both to be personally accountable for the authors' own contributions and to ensure that questions related to the accuracy or integrity of any part of the work, even ones in which the author was not personally involved, are appropriately investigated, resolved, and the resolution documented in the literature.

\section{Funding}

JEW is currently receiving grant funding from NCATS (\#KL2TR002245) and NIGMS (\#R01GM120484). BTP is currently receiving grant funding from NHLBI (\#R01HL14678-01). EWE is currently receiving grant funding from NIA (\#R01AG058639) and NIGMS (\#R01GM120484) serves as a consultant for Pfizer and Eli Lilly. The funding sources had no role in the preparation, review, or approval of the manuscript and decision to submit the manuscript for publication.

\section{Availability of data and materials \\ Not applicable.}

\section{Ethics approval and consent to participate}

Not applicable.

\section{Consent for publication}

Not applicable.

\section{Competing interests}

None.

\section{Author details}

${ }^{1}$ Department Anaesthesiology, Intensive Therapy and Acute Intoxications, Pomeranian Medical University, Al. Powstańców Wielkopolskich 72, 70-11 Szczecin, Poland. ${ }^{2}$ Critical IIIness, Brain Dysfunction, and Survivorship (CIBS) Center, Vanderbilt University Medical Center, Nashville, TN, USA. ${ }^{3}$ Department of Neurology, Vanderbilt University Medical Center, Nashville, TN, USA. ${ }^{4}$ Department of Bioengineering, Vanderbilt University, Nashville, TN, USA. ${ }^{5}$ Department of Psychiatry and Behavioral Sciences, Vanderbilt University Medical Center, Nashville, TN, USA. ${ }^{6}$ Geriatric Research, Education and Clinical Center (GRECC), Tennessee Valley Veterans Affairs Healthcare System, Nashville, TN, USA. 'Department of Anaesthesiology and Intensive Care, Medical University of Lublin, Lublin, Poland. ${ }^{8}$ Division of Allergy, Pulmonary, and Critical Care Medicine, Vanderbilt University Medical Center, Nashville, TN, USA.

\section{Received: 29 March 2020 Accepted: 8 April 2020}

\section{Published online: 28 April 2020}

\section{References}

1. General's opening remarks at the media briefing on COVID-19. https://www. who.int/dg/speeches/detail/who-director-general-s-opening-remarks-at-themedia-briefing-on-covid-19\%2D\%2D-11-march-2020. Accessed 26 Mar 2020.

2. Xu J, Zhong S, Liu J, Li L, Li Y, Wu X, Li Z, Deng P, Zhang J, Zhong N, et al. Detection of severe acute respiratory syndrome coronavirus in the brain: potential role of the chemokine mig in pathogenesis. Clin Infect Dis. 2005. 41(8):1089-96.

3. Lau KK, Yu WC, Chu CM, Lau ST, Sheng B, Yuen KY. Possible central nervous system infection by SARS coronavirus. Emerg Infect Dis. 2004;10(2):342-4.

4. Bergmann CC, Lane TE, Stohlman SA. Coronavirus infection of the central nervous system: host-virus stand-off. Nat Rev Microbiol. 2006;4(2):121-32.

5. Pilli D, Zou A, Tea F, Dale RC, Brilot F. Expanding role of T cells in human autoimmune diseases of the central nervous system. Front Immunol. 2017;8: 652.

6. Maldonado JR. Delirium pathophysiology: an updated hypothesis of the etiology of acute brain failure. Int J Geriatr Psychiatry. 2018;33(11):1428-57.

7. Vasilevskis E, Pandharipande P, Graves A, Shintani A, Tsuruta R, Ely EW, Girard TD. Validation of a modified Sequential Organ Failure Assessment
(SOFA) score incorporating the Richmond Agitation-Sedation Score (RASS) to assess neurologic end-organ function. Am J Respir Crit Care Med. 2013; 187:A1551.

8. Mao L, Jin H, Wang M, et al. Neurologic Manifestations of Hospitalized Patients With Coronavirus Disease 2019 in Wuhan, China. JAMA Neurol. 2020;e201127. https://doi.org/10.1001/jamaneurol.2020.1127.

9. Francis J, Martin D, Kapoor WN. A prospective study of delirium in hospitalized elderly. JAMA. 1990;263(8):1097-101.

10. Elie M, Rousseau F, Cole M, Primeau F, McCusker J, Bellavance F. Prevalence and detection of delirium in elderly emergency department patients. CMAJ. 2000;163(8):977-81.

11. Inouye SK, Foreman MD, Mion LC, Katz KH, Cooney LM Jr. Nurses' recognition of delirium and its symptoms: comparison of nurse and researcher ratings. Arch Intern Med. 2001;161(20):2467-73.

12. Han JH, Zimmerman EE, Cutler N, Schnelle J, Morandi A, Dittus RS, Storrow $A B$, Ely EW. Delirium in older emergency department patients: recognition, risk factors, and psychomotor subtypes. AcadEmergMed. 2009;16(3):193200.

13. van Eijk MM, van Marum RJ, Klijn IA, de Wit N, Kesecioglu J, Slooter AJ. Comparison of delirium assessment tools in a mixed intensive care unit. Crit Care Med. 2009;37(6):1881-5.

14. Spronk PE, Riekerk B, Hofhuis J, Rommes JH. Occurrence of delirium is severely underestimated in the ICU during daily care. Intens Care Med. 2009;35(7):1276-80.

15. Grossmann FF, Hasemann W, Graber A, Bingisser R, Kressig RW, Nickel CH. Screening, detection and management of delirium in the emergency department - a pilot study on the feasibility of a new algorithm for use in older emergency department patients: the modified Confusion Assessment Method for the Emergency Department (mCAM-ED). Scand J Trauma Resusc Emerg Med. 2014;22:19.

16. Iwashyna TJ, Netzer G. The burdens of survivorship: an approach to thinking about long-term outcomes after critical illness. Semin Respir Crit Care Med. 2012;33(4):327-38.

17. Needham DM, Davidson J, Cohen H, Hopkins RO, Weinert C, Wunsch H, Zawistowski C, Bemis-Dougherty A, Berney SC, Bienvenu OJ, et al. Improving long-term outcomes after discharge from intensive care unit: report from a stakeholders' conference. Crit Care Med. 2012;40(2):502-9.

18. Davidson JE, Aslakson RA, Long AC, Puntillo KA, Kross EK, Hart J, Cox CE, Wunsch H, Wickline MA, Nunnally ME, et al. Guidelines for family-centered care in the neonatal, pediatric, and adult ICU. Crit Care Med. 2017:45(1):10328.

19. Qiu HB, Li XY, Du B, HYJ K, Wang YS, Wang F, Sun B, Tong ZH. The keypoints in treatment of the critical novel coronavirus pneumonia patient. Zhonghua jie he he hu xi za zhi. 2020;43(0):E022.

20. American Psychiatric Association. Diagnostic and Statistical Manual of Mental Disorders. 5th ed. Arlington: American Psychiatric Association; 2013.

21. Tsuruta R, Oda Y. A clinical perspective of sepsis-associated delirium. J Intensive Care. 2016;4:18.

22. Ely EW, Inouye SK, Bernard GR, Gordon S, Francis J, May L, Truman B, Speroff T, Gautam S, Margolin R, et al. Delirium in mechanically ventilated patients: validity and reliability of the confusion assessment method for the intensive care unit (CAM-ICU). Jama. 2001;286(21):2703-10.

23. Bergeron N, Dubois MJ, Dumont M, Dial S, Skrobik Y. Intensive Care Delirium Screening Checklist: evaluation of a new screening tool. Intensive Care Med. 2001;27(5):859-64.

24. Marra A, Kotfis K, Hosie A, MacLullich AMJ, Pandharipande PP, Ely EW, Pun BT. Delirium monitoring: yes or no? That is the question. Am J Crit Care. 2019;28(2):127-35

25. Gusmao-Flores D, Salluh Jl, Chalhub RA, Quarantini LC. The confusion assessment method for the intensive care unit (CAM-ICU) and intensive care delirium screening checklist (ICDSC) for the diagnosis of delirium: a systematic review and meta-analysis of clinical studies. Crit Care. 2012;16(4): R115.

26. Barr J, Fraser GL, Puntillo K, Ely EW, Gelinas C, Dasta JF, Davidson JE, Devlin $J W$, Kress JP, Joffe AM, et al. Clinical practice guidelines for the management of pain, agitation, and delirium in adult patients in the intensive care unit. Crit Care Med. 2013;41 (1):263-306.

27. Trzepacz PT, Mittal D, Torres R, Kanary K, Norton J, Jimerson N. Validation of the Delirium Rating Scale-revised-98: comparison with the delirium rating scale and the cognitive test for delirium. J Neuropsychiatry Clin Neurosci. 2001;13(2):229-42. 
28. Khan BA, Perkins AJ, Gao S, Hui SL, Campbell NL, Farber MO, Chlan LL, Boustani MA. The confusion assessment method for the ICU-7 delirium severity scale: a novel delirium severity instrument for use in the ICU. Crit Care Med. 2017;45(5):851-7.

29. Ely EW, Margolin R, Francis J, May L, Truman B, Dittus R, Speroff T, Gautam S, Bernard GR, Inouye SK. Evaluation of delirium in critically ill patients: validation of the Confusion Assessment Method for the Intensive Care Unit (CAM-ICU). Crit Care Med. 2001;29(7):1370-9.

30. Radtke FM, Franck M, Oppermann S, Lutz A, Seeling M, Heymann A, Kleinwachter R, Kork F, Skrobik Y, Spies CD. The Intensive Care Delirium Screening Checklist (ICDSC)--translation and validation of intensive care delirium checklist in accordance with guidelines. Anasthesiol Intensivmed Notfallmed Schmerzther. 2009;44(2):80-6.

31. Zhu N, Zhang D, Wang W, Li X, Yang B, Song J, Zhao X, Huang B, Shi W, Lu $R$, et al. A novel coronavirus from patients with pneumonia in China, 2019. N Engl J Med. 2020;382(8):727-33.

32. Li Q, Guan X, Wu P, Wang X, Zhou L, Tong Y, Ren R, Leung KSM, Lau EHY, Wong JY, et al. Early transmission dynamics in Wuhan, China, of novel coronavirus-infected pneumonia. N Engl J Med. 2020;382(13):1199-207.

33. Huang C, Wang Y, Li X, Ren L, Zhao J, Hu Y, Zhang L, Fan G, Xu J, Gu X, et al. Clinical features of patients infected with 2019 novel coronavirus in Wuhan, China. Lancet. 2020;395(10223):497-506.

34. Emanuel EJ, Persad G, Upshur R, et al. Fair Allocation of Scarce Medical Resources in the Time of Covid-19. N Engl J Med. 2020. https://doi.org/10. 1056/NEJMsb2005114.

35. Pandharipande PP, Shintani A, Peterson J, Ely EW. Sedative and analgesic medications are independent risk factors in ICU patients for transitioning into delirium. Crit Care Med. 2004;32:A19.

36. Han L, McCusker J, Cole M, Abrahamowicz M, Primeau F, Elie M. Use of medications with anticholinergic effect predicts clinical severity of delirium symptoms in older medical inpatients. Arch Intern Med. 2001;161 (8):1099-105.

37. Pun BT, Balas MC, Barnes-Daly MA, Thompson JL, Aldrich JM, Barr J, Byrum D, Carson SS, Devlin JW, Engel HJ, et al. Caring for critically ill patients with the ABCDEF bundle: results of the ICU liberation collaborative in over 15,000 adults. Crit Care Med. 2019;47(1):3-14.

38. Ely EW. The ABCDEF bundle: science and philosophy of how ICU liberation serves patients and families. Crit Care Med. 2017:45(2):321-30.

39. Barnes-Daly MA, Phillips G, Ely EW. Improving hospital survival and reducing brain dysfunction at seven California community hospitals: implementing PAD guidelines via the ABCDEF bundle in 6,064 patients. Crit Care Med. 2017;45(2):171-8.

40. Caridi-Scheible M. Clinical and team management in the COVID-ICU: successful strategies from the first week. In: COVID-19 Clinical Rounds. Atlanta: Emory Critical Care Center; 2019.

41. Ding Y, He L, Zhang Q, Huang Z, Che X, Hou J, Wang H, Shen H, Qiu $L$, Li Z, et al. Organ distribution of severe acute respiratory syndrome (SARS) associated coronavirus (SARS-CoV) in SARS patients: implications for pathogenesis and virus transmission pathways. J Pathol. 2004;203(2): 622-30.

42. Gu J, Gong E, Zhang B, Zheng J, Gao Z, Zhong Y, Zou W, Zhan J, Wang S, Xie $Z$, et al. Multiple organ infection and the pathogenesis of SARS. J Exp Med. 2005;202(3):415-24.

43. Li YC, Bai WZ, Hirano N, Hayashida T, Taniguchi T, Sugita Y, Tohyama K, Hashikawa T. Neurotropic virus tracing suggests a membranous-coatingmediated mechanism for transsynaptic communication. J Comp Neurol. 2013;521(1):203-12.

44. Hui DS, Wong PC, Wang C. SARS: clinical features and diagnosis. Respirol. 2003;8(Suppl):S20-4

45. Li YC, Bai WZ, Hashikawa T. The neuroinvasive potential of SARS-CoV2 may play a role in the respiratory failure of COVID-19 patients. J Med Virol. 2020. https://doi.org/10.1002/jmv.25728.

46. Glass WG, Subbarao K, Murphy B, Murphy PM. Mechanisms of host defense following severe acute respiratory syndrome-coronavirus (SARS-CoV) pulmonary infection of mice. J Immunol. 2004;173(6):4030-9.

47. Arbour N, Day R, Newcombe J, Talbot PJ. Neuroinvasion by human respiratory coronaviruses. J Virol. 2000;74(19):8913-21.

48. Li K, Wohlford-Lenane C, Perlman S, Zhao J, Jewell AK, Reznikov LR, Gibson-Corley KN, Meyerholz DK, McCray PB Jr. Middle East respiratory syndrome coronavirus causes multiple organ damage and lethal disease in mice transgenic for human Dipeptidyl peptidase 4. J Infect Dis. 2016; 213(5):712-22
49. Khan S, Ali A, Siddique R, Nabi G. Novel coronavirus is putting the whole world on alert. J Hosp Infect. 2020;104(3):252-3.

50. Talbot PJ, Ekande S, Cashman NR, Mounir S, Stewart JN. Neurotropism of human coronavirus 229E. Adv Exp Med Biol. 1993:342:339-46.

51. Mengeling WL, Boothe AD, Ritchie AE. Characteristics of a coronavirus (strain 67N) of pigs. Am J Vet Res. 1972;33(2):297-308.

52. Yeh EA, Collins A, Cohen ME, Duffner PK, Faden H. Detection of coronavirus in the central nervous system of a child with acute disseminated encephalomyelitis. Pediatrics. 2004;113(1 Pt 1):e73-6.

53. Nath A. Neurologic complications of coronavirus infections. Neurology 2020. https://doi.org/10.1212/WNL.0000000000009455.

54. Li Y, Li H, Fan R, Wen B, Zhang J, Cao X, Wang C, Song Z, Li S, Li X, et al. Coronavirus infections in the central nervous system and respiratory tract show distinct features in hospitalized children. Intervirology. 2016;59(3):163-9.

55. Poyiadji N, Shahin G, Noujaim D, Stone M, Patel S, Griffith B. COVID-19associated Acute Hemorrhagic Necrotizing Encephalopathy: CT and MR Features. Radiology. 2020. p. 201187. https://doi.org/10.1148/radiol. 2020201187.

56. Li YC, Bai WZ, Hirano N, Hayashida T, Hashikawa T. Coronavirus infection of rat dorsal root ganglia: ultrastructural characterization of viral replication, transfer, and the early response of satellite cells. Virus Res. 2012;163(2):628-35.

57. Netland J, Meyerholz DK, Moore S, Cassell M, Perlman S. Severe acute respiratory syndrome coronavirus infection causes neuronal death in the absence of encephalitis in mice transgenic for human ACE2. J Virol. 2008; 82(15):7264-75.

58. Kotfis K, Skonieczna-Żydecka K. COVID-19: gastrointestinal symptoms and potential sources of 2019-nCoV transmission. Anaesthesiol Intensive Ther. 2020;40157. https://doi.org/10.5114/ait.2020.93867.

59. Baig AM, Khaleeq A, Ali U, Syeda H. Evidence of the COVID-19 virus targeting the CNS: tissue distribution, host-virus interaction, and proposed neurotropic mechanisms. ACS Chem Neurosci. 2020;11(7):995-8.

60. Wiesmann M, Kiliaan AJ, Claassen JA. Vascular aspects of cognitive impairment and dementia. J Cereb Blood Flow Metab. 2013;33(11): 1696-706.

61. Rygiel K. Can angiotensin-converting enzyme inhibitors impact cognitive decline in early stages of Alzheimer's disease? An overview of research evidence in the elderly patient population. J Postgrad Med. 2016:62(4):242-8.

62. Palmer JC, Tayler HM, Love S. Endothelin-converting enzyme-1 activity, endothelin-1 production, and free radical-dependent vasoconstriction in Alzheimer's disease. J Alzheimers Dis. 2013:36(3):577-87.

63. Martire S, Mosca L, d'Erme M. PARP-1 involvement in neurodegeneration: a focus on Alzheimer's and Parkinson's diseases. Mech Ageing Dev. 2015;146148:53-64.

64. lacono KT, Kazi L, Weiss SR. Both spike and background genes contribute to murine coronavirus neurovirulence. J Virol. 2006;80(14):6834-43.

65. Zhou J, Stohlman SA, Hinton DR, Marten NW. Neutrophils promote mononuclear cell infiltration during viral-induced encephalitis. J Immunol. 2003;170(6):3331-6.

66. Templeton SP, Kim TS, O'Malley K, Perlman S. Maturation and localization of macrophages and microglia during infection with a neurotropic murine coronavirus. Brain pathology. 2008;18(1):40-51.

67. Kim LJ, Martinez D, Fiori CZ, Baronio D, Kretzmann NA, Barros HM. Hypomyelination, memory impairment, and blood-brain barrier permeability in a model of sleep apnea. Brain Res. 2015;1597:28-36.

68. Sun JJ, Ren QG, Xu L, Zhang ZJ. LINGO-1 antibody ameliorates myelin impairment and spatial memory deficits in experimental autoimmune encephalomyelitis mice. Sci Rep. 2015;5:14235.

69. Dubé M, Le Coupanec A, Wong AHM, Rini JM, Desforges M, Talbot PJ. Axonal Transport Enables Neuron-to-Neuron Propagation of Human Coronavirus OC43. J Virol. 2018;92(17):e00404-18. https://doi.org/10.1128/JVI. 00404-18.

70. Ely EW, Gautam S, Margolin R, Francis J, May L, Speroff T, Truman B, Dittus R, Bernard $R$, Inouye SK. The impact of delirium in the intensive care unit on hospital length of stay. Intensive Care Med. 2001;27(12):1892-900.

71. Ely EW, Shintani A, Truman B, Speroff T, Gordon SM, Harrell FE Jr, Inouye SK, Bernard GR, Dittus RS. Delirium as a predictor of mortality in mechanically ventilated patients in the intensive care unit. JAMA. 2004; 291(14):1753-62. 
72. Vasilevskis EE, Chandrasekhar R, Holtze CH, Graves J, Speroff T, Girard TD, Patel MB, Hughes CG, Cao A, Pandharipande PP, et al. The cost of ICU delirium and coma in the intensive care unit patient. Med Care. 2018;56(10):890-7.

73. Pandharipande PP, Girard TD, Jackson JC, Morandi A, Thompson JL, Pun BT, Brummel NE, Hughes CG, Vasilevskis EE, Shintani AK, et al. Longterm cognitive impairment after critical illness. N Engl J Med. 2013; 369(14):1306-16.

74. Vincent JL, Shehabi Y, Walsh TS, Pandharipande PP, Ball JA, Spronk P, Longrois D, Strom T, Conti G, Funk GC, et al. Comfort and patient-centred care without excessive sedation: the eCASH concept. Intensive Care Med. 2016;42(6):962-71.

75. Girard TD, Thompson JL, Pandharipande PP, Brummel NE, Jackson JC, Patel MB, Hughes CG, Chandrasekhar R, Pun BT, Boehm LM, et al. Clinical phenotypes of delirium during critical illness and severity of subsequent long-term cognitive impairment: a prospective cohort study. Lancet Respir Med. 2018;6(3):213-22.

76. Girard TD, Dittus RS, Ely EW. Critical illness brain injury. Annu Rev Med. 2016; 67:497-513.

77. Pandharipande P, Cotton BA, Shintani A, Thompson J, Pun BT, Morris JA Jr, Dittus R, Ely EW. Prevalence and risk factors for development of delirium in surgical and trauma intensive care unit patients. J Trauma. 2008;65(1):34-41.

78. Pandharipande P, Shintani A, Peterson J, Pun BT, Wilkinson GR, Dittus RS, Bernard GR, Ely EW. Lorazepam is an independent risk factor for transitioning to delirium in intensive care unit patients. Anesthesiology. 2006;104(1):21-6.

79. Girard TD, Exline MC, Carson SS, et al. Haloperidol and Ziprasidone for Treatment of Delirium in Critical IIIness. N Engl J Med. 2018;379(26):2506-16. https://doi.org/10.1056/NEJMoa1808217.

80. van den Boogaard M, Slooter AJC, Bruggemann RJM, Schoonhoven L, Beishuizen A, Vermeijden JW, Pretorius D, de Koning J, Simons KS, Dennesen PJW, et al. Effect of haloperidol on survival among critically ill adults with a high risk of delirium: the REDUCE randomized clinical trial. JAMA. 2018;319(7):680-90,

81. Meng L, Qiu H, Wan L, et al. Intubation and Ventilation amid the COVID-19 Outbreak: Wuhan's Experience. Anesthesiology. 2020. https://doi.org/10. 1097/ALN.0000000000003296.

82. Balas M, Olsen K, Gannon D, Sisson J, Sullivan J, Stothert J, Jawa R Vasilevskis E, Burke W, Ely W. Safety and efficacy of the Abcde bundle in critically-ill patients receiving mechanical ventilation. Crit Care Med. 2012; 40(12):U18.

83. Hsieh SJ, Otusanya O, Gershengorn HB, Hope AA, Dayton C, Levi D, Garcia $M$, Prince $D$, Mills $M$, Fein $D$, et al. Staged implementation of awakening and breathing, coordination, delirium monitoring and management, and early mobilization bundle improves patient outcomes and reduces hospital costs. Crit Care Med. 2019;47(7):885-93.

84. Barnes-Daly MA, Pun BT, Harmon LA, Byrum DG, Kumar VK, Devlin JW, Stollings JL, Puntillo KA, Engel HJ, Posa PJ, et al. Improving health care for critically ill patients using an evidence-based collaborative approach to ABCDEF bundle dissemination and implementation. Worldviews Evid-Based Nurs. 2018:15(3):206-16.

85. Kotfis K, Marra A, Ely EW. ICU delirium - a diagnostic and therapeutic challenge in the intensive care unit. Anaesthesiol Intensive Ther. 2018;50(2): 160-7.

\section{Publisher's Note}

Springer Nature remains neutral with regard to jurisdictional claims in published maps and institutional affiliations. 